Transactions of the American Fisheries Society, 1987, v.116, n.2, pp.210-223. http://afsjournals.org/ DOI: 10.1577/1548-8659(1987)116<196:LCIFAA>2.0.CO;2 ISSN: 0002-8487

(C) American Fisheries Society 


\title{
Eutrophication Effects on Prey Size and Food Available to Yellow Perch in Lake Erie
}

\author{
Robert S. HAYward ANd F. Joseph MARgraF \\ Ohio Cooperative Fish and Wildlife Research Unit, ${ }^{1} 1735$ Neil Avenue \\ Columbus, Ohio 43210, USA
}

\begin{abstract}
Before 1970, yellow perch Perca flavescens grew at similar rates in Lake Erie's western and central basins. At that time, high rates of nutrient loading were causing rapid eutrophication in both areas so that by the mid-1970s the central basin had become mildly eutrophic while the shallow western basin had reached hypereutrophy. From 1970 to 1983 , growth rates of yellow perch in the western basin declined sharply while growth rates increased moderately in the central basin. Modeling of bioenergetics suggests that present differences in yellow perch growth rates are due to interbasin differences in food supply and not to temperature. Direct estimation of yellow perch feeding rates in each basin in 1983 supports this inference. Food limitation in the western basin appears related to a reduced size structure of benthic prey associated with advanced eutrophy. In the central basin, larger benthic prey are available and food consumption rates by yellow perch are high. Food limitation is more serious for larger than for smaller yellow perch in the western basin, and this has apparently caused stunting and population degradation. Further evidence from the literature suggests that changes in prey size structure which accompany eutrophication may be a primary cuase of the succession of fish species that occurs as lakes age. Mechanistic understanding of this succession will enhance present capacity to predict fish community responses both to ongoing eutrophication and to the more recent oligotrophication of lakes.
\end{abstract}

Patterns of succession of fish species in response to lake eutrophication have been recognized from observations on individual systems (Biro 1977; Hartmann and Numann 1977) and from comparisons among lakes in different trophic stages (Colby et al. 1972; Entz 1977; Leopold et al. 1986). These patterns show that certain processes associated with eutrophication exert a structuring influence on fish communities. Identification of key structuring processes would enhance basic understanding and allow mechanistic evaluation of the scope for well-being of fish populations as determined by lake trophic stage (Leach et al. 1977). Knowledge of successional processes would broaden the basis for projecting responses of fish communities to further eutrophication of lakes or, more recently, the oligotrophication of lakes (USEPA 1985; Sabourin et al., in press). Presently, such projections are based almost solely on empirical descriptions of patterns of succession in individual systems (Leopold et al. 1986).

Changes in lake environments that are broadly characteristic of eutrophication have been identified (Colby et al. 1972; Hartmann and Numann 1977; Leach et al. 1977) and are considered either individually or synergistically to cause the rises

${ }^{1}$ The unit is supported jointly by the U.S. Fish and Wildlife Service, Ohio Department of Natural Resources, and The Ohio State University. and declines of fish populations as the aging of a lake proceeds (Sniesko 1974; Leach and Nepszy 1976; Leopold et al. 1986). Empirical evidence for cause and effect, upon which mechanistic prediction can be based, has been very limited.

Lake Erie is a classical case of eutrophication in a large aquatic system (Arnold 1969; Rathke and Edwards 1985) where rises and declines of numerous fish populations have been documented over the past 100 years (Hartman 1972; Regier and Hartman 1973; Leach and Nepszy 1976). Confounding effects of heavy commercial fishing, introductions of exotic species, habitat alterations, and toxic effects have, unfortunately, muddled a clear picture of the fish community's response to cultural eutrophication (Christie 1974; Leach and Nepszy 1976). Still, a prevailing influence of eutrophication was evident when rates of change in biotic communities increased coincident with pronounced increases in phosphorus loading rates into the lake around 1950 (Britt 1955; Beeton 1961; Great Lakes Basin Commission 1976).

Prior to 1950, yellow perch Percaflavescens grew at similar rates in Lake Erie's western and central basins (Jobes 1952). More recent evidence (Hartman et al. 1980) indicates that no major changes in their growth rates occurred through the 1960s. Beginning around 1970, however, growth rates in what had become a highly eutrophic western basin began a decline that has persisted through the time of this study. In contrast, growth rates in the less 


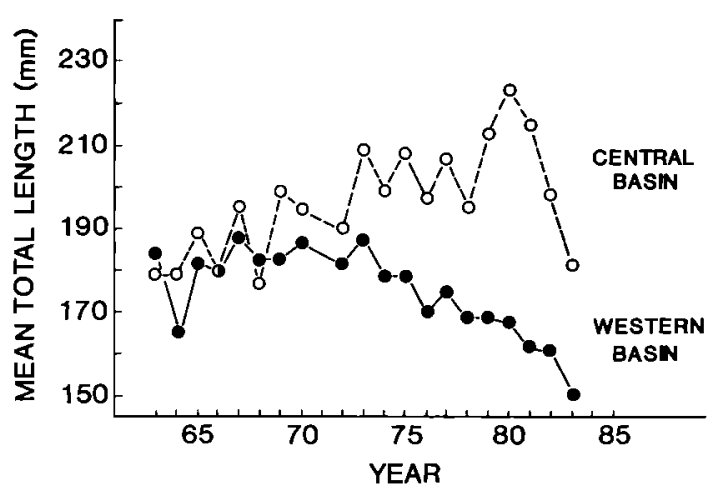

Figure 1.-Mean total lengths of age-2+ yellow perch collected by bottom trawling in the western and central basins of Lake Erie during October 1963-1983. Data were provided by Roger Knight, Ohio Department of Natural Resources, Lake Erie Fisheries Research Unit.

eutrophic central basin have, until recently, increased slightly since the 1960s (Figure 1).

We used a bioenergetics approach in an attempt to understand why yellow perch now grow at different rates in the two basins. Initially, we hypothesized that interbasin differences in thermal regime and food supply cause present growth rate differences. Our interest in temperature effects on interbasin growth differences arose from earlier evidence that size differences in the western and eastern basins were partially due to disparate thermal regimes (Kitchell et al. 1977). We used bioenergetics modeling to reduce our two-component hypothesis (food supply and temperature) to one with a single component, which we then tested in the field. Agreement between modeling and fieldstudy results indicates why yellow perch growth rates presently differ. When viewed in light of an earlier diet study (Price 1963) and known eutrophication effects on the benthic fauna (Carr and Hiltunen 1965), our results indicate a mechanism through which eutrophication has influenced wellbeing of Lake Erie yellow perch. Evidence can be found in the literature that this mechanism, which parallels Lindeman's (1942) trophic-dynamic viewpoint, may broadly underlie fish species succession.

\section{Background on Lake Erie}

Lake Erie comprises three basins (the western, central, and eastern) which become progressively deeper to the east; our study focuses on the western and central basins. Numerous reports on physical, chemical, and biological aspects of the lake have been completed (see Great Lakes Basin Commission 1976). Loading rates of total phosphorus into Lake Erie increased markedly around 1950 , reaching highest input levels in the early 1970s (Sly 1976). The resultant eutrophication differed among the three basins chiefly because of differences in morphometry. By the early 1970 s, the shallow western basin $(<11 \mathrm{~m}$ deep) had become highly eutrophic while the deeper $(<25 \mathrm{~m})$ central basin had reached mild eutrophy (Vollenweider et al. 1974).

Knowledge of prey community responses to eutrophication of the lake varies. Increases in phytoplankton standing crops coincident with increased nutrient loading are apparent from a series of descriptive studies (Davis 1964; Great Lakes Basin Commission 1976; Munawar and Munawar 1976), as is a shift away from diatom predominance towards an increasing presence of green and blue-green algae. The zooplankton record, though fragmented, shows increases in copepod and cladoceran biomasses and shifts in the species assemblages (Bradshaw 1964; Larson and Rathke 1980). Unlike the plankton record, changes in the benthic fauna (at least in the western basin) are well defined and closely linked to the rapid eutrophication. Carr and Hiltunen (1965) compared abundance, composition, and distribution of the western basin benthos in 1961 with its earlier complexion in 1930 by methods identical to the earlier study (Wright 1955). They linked changes in the benthos to processes of eutrophication by mapping the lakeward expansion of areas inhabited by "tolerant" species (oligochaetes and certain chironomids) outward from the culturally polluted rivers. Areas inhabited by larger, "intolerant" benthos (e.g., mayflies Hexagenia spp. and amphipods) had already shown substantial lakeward recession by 1961. Evidence suggests that a stable biomass of forage fish has existed since 1960, but a shift from cyprinid to clupeid predominance has occurred (K. Muth, U.S. Fish and Wildlife Service, Great Lakes Fishery Laboratory, personal communication).

Recent assessments show that highest phosphorus input rates for Lake Erie (in the 1970s) were cut twofold by the early 1980s (Rathke and Edwards 1985). Indications of a much reduced eutrophication rate have emerged (International Joint Commission 1983) and signs of a reversal of trophic stage in both the western and central basins are currently being sought. Evidence for the persistence of reduced size structure of the western basin benthos into the 1980 s, however, was pro- 
vided in a 1982 survey (B. Manny, U.S. Fish and Wildlife Service, Great Lakes Fishery Laboratory, personal communication), and it is of particular relevance to this study.

\section{Methods}

Modeling. - We first evaluated temperature differences between the basins as a cause of the differential growth of yellow perch. Temperature and dissolved oxygen profiles from throughout the western and central basins (Ohio State University, Center for Lake Erie Area Research, unpublished data) were evaluated for 1978-1981 to develop a thermal experience curve for yellow perch in each basin. Because the western basin rarely stratifies, we averaged over sites and depths to derive an annual curve. We used the same approach for the central basin during nonstratified periods. When thermal stratification occurred, we assumed that yellow perch sought those water strata with oxygen concentrations of at least $3.0 \mathrm{mg} / \mathrm{L}$ that were closest to $23^{\circ} \mathrm{C}$ (the optimum temperature for yellow perch growth). Yellow perch have been shown to select approximately this temperature (Barans and Tubb 1973; McCauley and Read 1973), and this assumption also tended to maximize the effect of interbasin temperature differences on growth in the modeling process.

The bioenergetics model for yellow perch defines relationships among temperature, feeding rate, and somatic growth (Kitchell et al. 1977). Time series of values for any two of these variables allow the third variable to be solved. The first inputs to the model were the thermal experience curve and biweekly mean weights by age for yellow perch in the western basin. Growth data were obtained from biweekly bottom trawl collections (1979-1980) from a single site in the western basin (Crites 1982). Recent seasonal growth data for central basin fish were not available. Output from step 1 was a time series of feeding rates of western basin fish expressed as proportions of daily maxima. We then entered equivalent feeding rates (same proportions of maximum consumption) with the thermal experience curve for the central basin and a starting body weight equal to that for western basin fish. Growth of fish feeding at equivalent rations but under the thermal experience of central basin fish was then simulated. Differences between the observed growth curves for western basin fish and modeled growth curves for fish in the central basin are attributable to temperature.

To examine the effect of differing feeding rates on yellow perch growth, we simulated 10 and $25 \%$ increases of the average daily feeding rates previously derived for western basin fish. Resultant growth increases were compared to growth differences attributable to the interbasin thermal effect.

Field study. - To estimate growth and feeding rates empirically, we collected yellow perch at primary sampling sites in the offshore waters of the western (Near Middle Sister Island) and central (near Fairport, Ohio) basins during 1983 (Figure 2). All collections were made from the Ohio Division of Wildlife's research vessel, Explorer II. Each primary site was sampled over a 24 -h period (diel sampling) once per season in spring, summer, and fall. Ten-minute bottom trawls were done at 3-h intervals beginning at either 1400 or 1700 hours and continuing through 1400 hours on the following day. Gill nets were set on the bottom (within $150 \mathrm{~m}$ of trawling lanes) for 2.5 -h periods, bracketing trawl collections at 1100,1400, 2300, and 0200 hours. Immediately after each collection, yellow perch were placed in bags and quickfrozen on dry ice.

Additional single trawl collections were made at Middle Sister between April and October so that, in combination with diel sampling, fish were collected about every $20 \mathrm{~d}$ at this primary site. Single trawl collections were also made at a secondary site in the western basin near Kelleys Island (Kelleys) at various times throughout the year (Figure 2). Three secondary sampling sites in the central basin (Vermilion, Lorain, and Cleveland) were sampled by single trawl collections within a few days of each of the three diel sampling dates at Fairport. Each of the four central basin sites were sampled once again (single trawls) during late

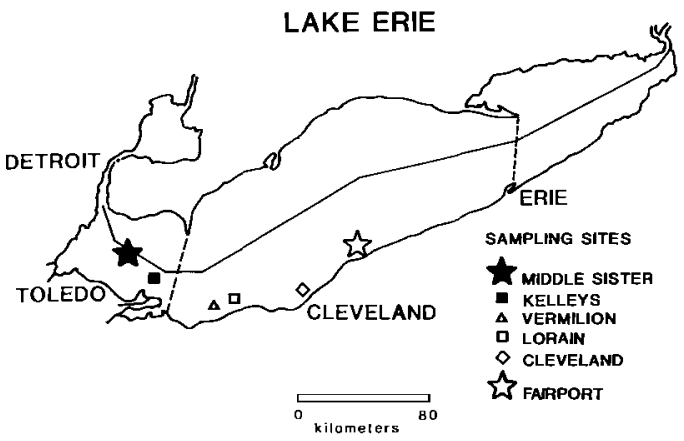

Figure 2.-Lake Erie, showing locations of primary (stars) and secondary (other symbols) sites at which yellow perch were sampled. Broken lines indicate boundaries separating the three lake basins; the solid line represents the U.S.-Canadian boundary. 
fall. Temperature and dissolved oxygen profiles were determined at each collection site on each outing.

In the laboratory, total lengths ( $\mathrm{mm}$ ), wet weights (g), and ages (scale method) were determined. Whole body dry weights $\left(72 \mathrm{~h}\right.$ at $\left.80^{\circ} \mathrm{C}\right)$ were estimated from regressions of dry weight on wet weight established for each diel outing. Individual food taxa for each fish taken in diel samples were identified and counted; for non-diel trawl collections, diet items were only cursorily identified as either fish or invertebrate. Stomach contents were weighed wet and then dry $\left(24 \mathrm{~h}\right.$ at $\left.80^{\circ} \mathrm{C}\right)$. Fish that had regurgitated food or had everted stomachs were not used to determine food consumption.

Food in the stomach of each fish in diel samples was expressed as the weight-specific ratio of dry weight of all food material to dry weight of the fish ( $\mathrm{g}$ food $\cdot \mathrm{g}$ fish $^{-1}$ ). Medians (and quartiles) of these ratios were determined for fish grouped into two length-classes (85-139 mm and 140-195 mm total length) based on comparisons of diet composition and quantity across yellow perch lengths. The decision to form only two groups partially reflects constraints of sample sizes. We also used $25-\mathrm{mm}$ length groups for some analyses. Point estimates (at 3-h intervals) of median food amounts in stomachs were converted to daily consumption rates ( $\mathrm{g}$ food $\cdot \mathrm{g}$ fish ${ }^{-1} \cdot \mathrm{d}^{-1}$ ) by the exponential algorithm of Elliot and Persson (1978). Instantaneous rates of gastric evacuation for yellow perch (required in the algorithm) were estimated from the functional relationship with temperature according to Persson (1979). When diel trawling spanned only 21 h (1700-1400 hours), the point estimate from the collection at 1400 hours on the second day was applied to the first sampling day to provide 24 -h coverage. The complete 24 -h series showed good agreement at 1400 hours on successive days.

We were also able to estimate daily food consumption from single trawl samples if they were taken at approximately 1100,1400 , or 1700 hours. From all diel outings, median weight-specific food quantities for these active feeding times were multiplied by Persson's (1979) temperature-dependent gastric evacuation rate $(R)$ and then regressed against calculated diel consumption rates (nine ordered pairs). Three significant regression relationships, incorporating information across fish sizegroups and seasons, were derived $\left(r^{2}=0.91,0.76\right.$, and 0.94 from collections made at 1100,1400 , and 1700 hours, respectively). A fourth significant regression based on combined information from trawls taken at all three times (the unweighted average of the three medians) was likewise defined, and it explained about $93 \%$ of the variability in daily food consumption. Yellow perch in the small size-group $(85-139 \mathrm{~mm})$ were absent from many of the trawl hauls during the summer diel series at Fairport. Daily food consumption rate for the small size-group was determined, therefore, by entering the temperature-adjusted median food amount $\left(R \cdot \mathrm{g}\right.$ food $\cdot \mathrm{g}$ fish $\left.{ }^{-1}\right)$ from the trawl collection at 1400 hours $(N=12$ stomachs) into our specific regression equation for that hour. We used a similar approach for both the large and small size-groups at Fairport for fall diel sampling when frequent eversion of stomachs reduced sample sizes. Results from trawl collections at 1100 , 1400 , and 1700 hours, as well as from gill-net data at 1400 hours, were entered into the combined regression to estimate food consumption for each size-group for the 24 -h period.

\section{Results}

\section{Modeling}

The shallow western basin warms more rapidly in spring than does the central basin and has temperatures closer to the growth optimum $\left(23^{\circ} \mathrm{C}\right)$ for yellow perch through early summer (Figure 3 ). In late summer, the thermal advantage switches to the central basin, where the optimal growth temperature prevails for about 1 month.

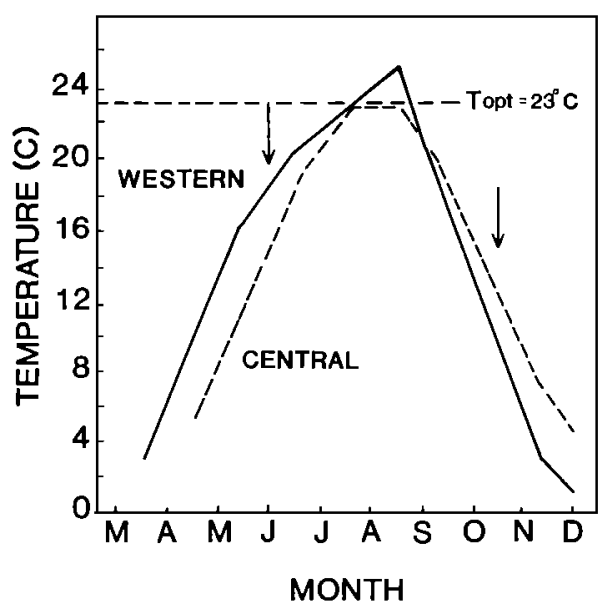

FIGURE 3.- Thermal-experience curves for yellow perch in the western and central basins of Lake Erie based on temperature profiles throughout each basin in 1978-1981. Arrows delimit the period over which temperature effects on growth were modeled. Optimal temperature for growth in model $\left(T_{\text {opt }}\right)$ was $23^{\circ} \mathrm{C}$. 


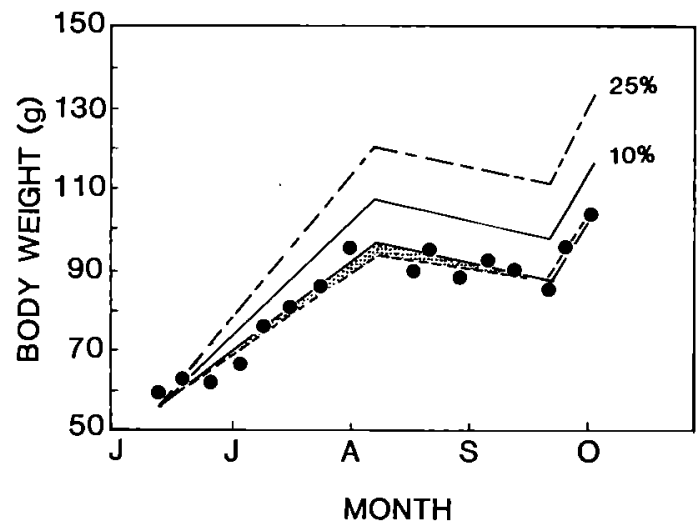

FIGURE 4. - Simulated change (shaded area) in the observed growth of 3-year-old Lake Erie yellow perch in 1979 (lower solid line and data points) when the central basin thermal regime was imposed on western basin fish, and simulated growth of fish when their daily ration was increased 10 and $25 \%$ over model-derived feeding rates for the western basin. Results are similar to those determined for other age-groups of yellow perch in 1979 and 1980.

When the growth of western basin yellow perch was modeled under the central basin thermal regime, the effect was negligible (Figure 4). In none of the simulations for age-classes 1,2 , and 3 in 1979 and 1980 did the thermal effect account for body weight differences of more than $2 \mathrm{~g}$, far less than weight differences that have been observed in the field. In contrast, simulations of modest increases (10 and $25 \%$ ) in daily ration resulted in substantial changes in body weight (Figure 4). Based on these results, we hypothesized that the interbasin differences in growth rates of yellow perch were due to differences in food consumption alone, not to temperature.

\section{Field Study}

Feeding rates. -During spring diel sampling, food amounts (medians) in yellow perch stomachs from the central basin exceeded amounts in western basin fish during each collection hour (Figure 5). In summer and fall, feeding curves overlapped considerably, except during heaviest feeding times, because food evacuation was more rapid at higher temperatures.

Daily feeding rates during diel sampling periods were greater in the central than in the western basin except for small yellow perch during midsummer and fall (Table 1). However, when feeding rates were expressed in standardized terms (relative to maintenance rations or maximum daily rates), values were always higher in the central

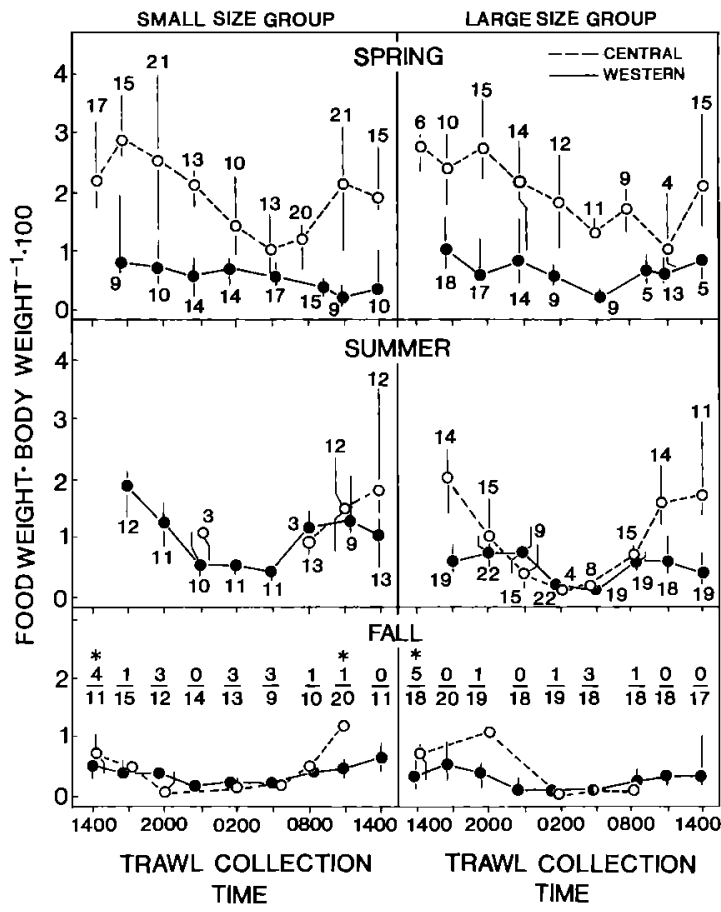

FIGUre 5.-Medians and quartiles of weight-specific food ratios ( $\mathrm{g}$ food $\cdot \mathrm{g}$ fish $\left.{ }^{-1} \cdot 100\right)$ for small $(85-139 \mathrm{~mm})$ and large (140-195 mm) yellow perch trawled at 3-h intervals from the central (Fairport) and western (Middle Sister) basins of Lake Erie, 1983. The numbers of stomachs examined are above curves or in numerators for the central basin, below curves or in denominators for the western basin. Asterisks $\left(^{*}\right)$ denote central basin samples that were augmented by gillnetted fish.

basin. Interbasin differences in food consumption were most pronounced for the larger fish, especially in summer and early fall when thermal conditions for growth were most favorable (Figure 6). Point estimates of daily feeding rates based on single trawl collections at Kelleys (western basin) and Vermilion (central basin) were consistent with seasonal feeding patterns at the respective primary sites (Figure 6), suggesting that primary stations yielded representative data for at least offshore areas of their basins.

Diets. - Pelagic chironomid pupae were the most frequently occurring prey in stomachs of all sizes of yellow perch in both basins during spring (Figure 7). Concentration by yellow perch on chironomid pupae has been observed previously in Lake Erie (D. Davies, Ohio Department of Natural Resources, personal communication). The exclusive use of chironomid pupae in spring at Fairport probably indicates coincidence of our sampling 
TABLE 1.-Food consumption rates, maintenance rations, and feeding rates as proportions of maximum daily consumption rates determined for yellow perch in the western and central basins of Lake Erie, based on diel sampling, 1983.

\begin{tabular}{|c|c|c|c|c|c|c|c|}
\hline \multicolumn{2}{|c|}{ Date } & \multicolumn{2}{|c|}{$\begin{array}{l}\text { Observed food consumption } \\
\text { rate }^{\mathrm{a}}\left(\mathrm{g} \text { food } \cdot \mathrm{g} \text { fish }^{-1} \cdot \mathrm{d}^{-1}\right)\end{array}$} & \multicolumn{2}{|c|}{$\begin{array}{l}\text { Maintenance ration }{ }^{b} \\
(\mathrm{~g} \text { food } \cdot \mathrm{g} \text { fish } \\
\left.-1 \cdot \mathrm{d}^{-1}\right)\end{array}$} & \multicolumn{2}{|c|}{$\begin{array}{c}\text { Proportion of } \\
\text { maximum consumption }\end{array}$} \\
\hline Western & Central & Western & Central & Western & Central & Western & Central \\
\hline \multicolumn{8}{|c|}{ Small size-group (fish 85-139 mm long) } \\
\hline May 24 & Jun 1 & 0.017 & 0.044 & 0.015 & 0.014 & 0.22 & 0.64 \\
\hline Jul I 3 & Jul 19 & 0.096 & $0.083^{*}$ & 0.029 & 0.022 & 0.72 & 0.86 \\
\hline Sep 8 & Sep 27 & 0.038 & $0.036^{\star}$ & 0.031 & 0.020 & 0.30 & 0.39 \\
\hline \multicolumn{8}{|c|}{ Large size-group (fish 140-195 mm long) } \\
\hline May 24 & Jun 1 & 0.019 & 0.041 & 0.012 & 0.010 & 0.37 & 0.86 \\
\hline Jul 13 & Jul 19 & 0.046 & 0.073 & 0.023 & 0.019 & 0.52 & 0.93 \\
\hline Sep 8 & Sep 27 & 0.028 & $0.035^{*}$ & 0.024 & 0.016 & 0.32 & 0.52 \\
\hline
\end{tabular}

a Estimates are based on nine successive trawls over $24 \mathrm{~h}$; those values derived from the regression relationship are designated by an asterisk (*).

b Values are based on equations from Kitchell et al. (I977).

c Observed feeding rate as a proportion of the maximum rate adjusted for temperature and body weight, from Kitchell et al. (1977).

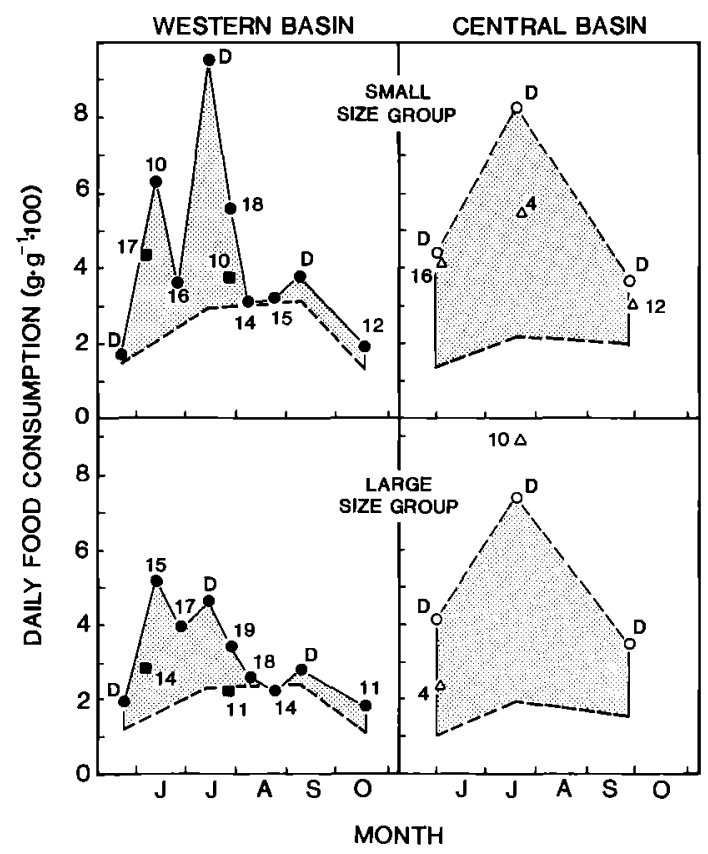

Figure 6.-Seasonal variation in daily food consumption rate ( $\mathrm{g}$ food $\mathrm{g}$ fish ${ }^{-1} \cdot 100$ ) in relation to maintenance rations (bottom lines in each panel) for small (85-139 mm) and large (140-195 mm) yellow perch collected near Middle Sister $(\boldsymbol{O})$ and Kelleys Island $(\boldsymbol{D})$ in the western basin of Lake Erie and from Fairport (O) and Vermilion $(\Delta)$ in the central basin. Data points are connected for primary stations only. Estimates based on single trawl collections show numbers of stomachs examined near data points; values from diel outings are indicated by " $D$ " (see Figure 5 for sample sizes). with an emergence event rather the absence of alternative prey.

The most striking interbasin differences in yellow perch diet composition were observed during summer sampling when food consumption rates were also most different between primary sites (Figure 6). At Fairport, all sizes of yellow perch fed readily on six major benthic taxa in addition to zooplankton (Figure 7). Benthic diet items (isopods, amphipods, chironomids, sphaeriid clams, leeches, and water mites) included taxa considered as intermediate- and large-sized (Hansson 1985). At Middle Sister, yellow perch less than $150 \mathrm{~mm}$ long fed only on chironomids, while larger individuals ate chironomids plus sphaeriid clams. Low diversity and small size of prey in the summer diet of western basin yellow perch were associated with a pronounced negative relationship between daily food consumption and fish size (Figure 8). While small western basin yellow perch consumed high amounts of food, individuals longer than 150 $\mathrm{mm}$ fed only near maintenance levels. In contrast, at Fairport, where a greater diversity of largersized benthos was eaten, food consumption values in summer were high for all fish sizes.

By fall, both diversity of consumed prey and feeding rates had declined in both basins. Some piscivory occurred then, but cursory evaluations of yellow perch diets throughout the year from single trawl collections (primarily in the western basin) indicated that forage fish never represented more than minor components in 1983 diets.

Growth rates. - Apparent growth rates of 1-, 2-, and 3-year-old yellow perch in 1983 were clearly higher in the central than in the western basin (Figure 9). Interbasin differences in growth were 


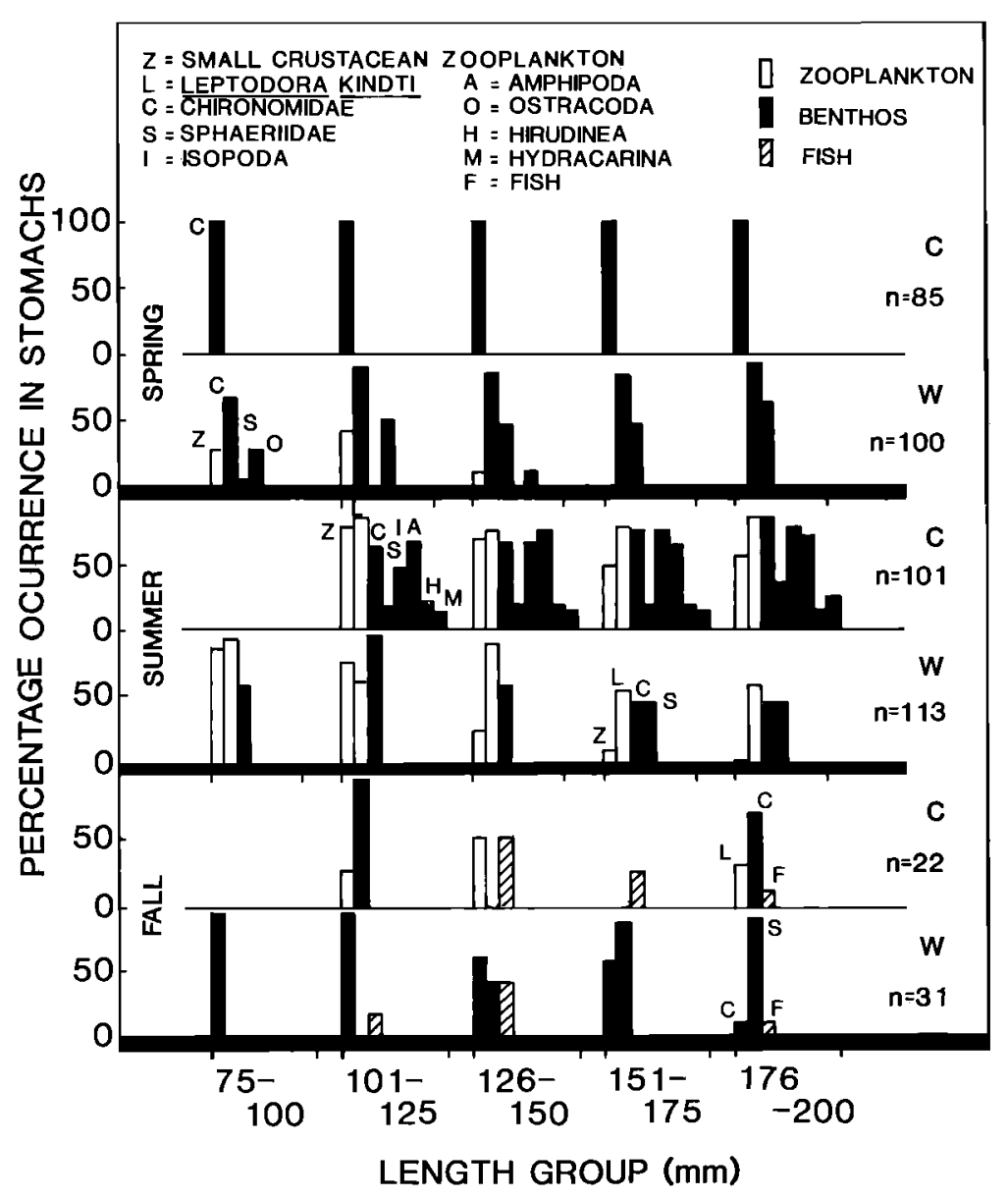

FIGURE 7.-Percentage of yellow perch stomachs containing individual food items during diel sampling in the central $(C)$ and western $(W)$ basins of Lake Erie, by season and predator length group, 1983; $n$ is number of stomachs examined. Only diet items that occurred at least once per 10 stomachs during a particular diel outing are presented. Taxa are arranged consistently along a row, but not down a column.

greatest for 3-year-olds which grew only slightly in the western basin after July, in accordance with observed low food consumption rates (Figure 6). Growth rates in 1983 increased progressively towards the east at sampling sites across both basins. Apparent declines in mean weights of central basin fish (particularly age 3 ) in late fall are believed to have resulted from selective removal of larger yellow perch by the intensive fall gill-net fishery (central basin only) where effort was greatest just after our September sampling (Davies, personal communication).

\section{Discussion}

\section{Significance of Modeling Results}

Through combinations of effects of thermal regime and food supply, yellow perch grew at sim- ilar rates in the western and central basins prior to 1950 (Jobes 1952). This equivalency in conditions for growth apparently persisted through the 1960s (Hartman et al. 1980), well after a number of dramatic biological responses to eutrophication had already been observed throughout the lake. Modeling of bioenergetics indicated that differences in thermal regimes in the two basins have but a negligible influence on interbasin growth differences. This result allowed us to conclude tentatively that changes in conditions for yellow perch growth have been largely due to changes in food supply for this species in each basin.

Field results clearly supported modeling conclusions by showing seasonally higher rates of food consumption by central basin yellow perch. A direct relationship between available food supply 


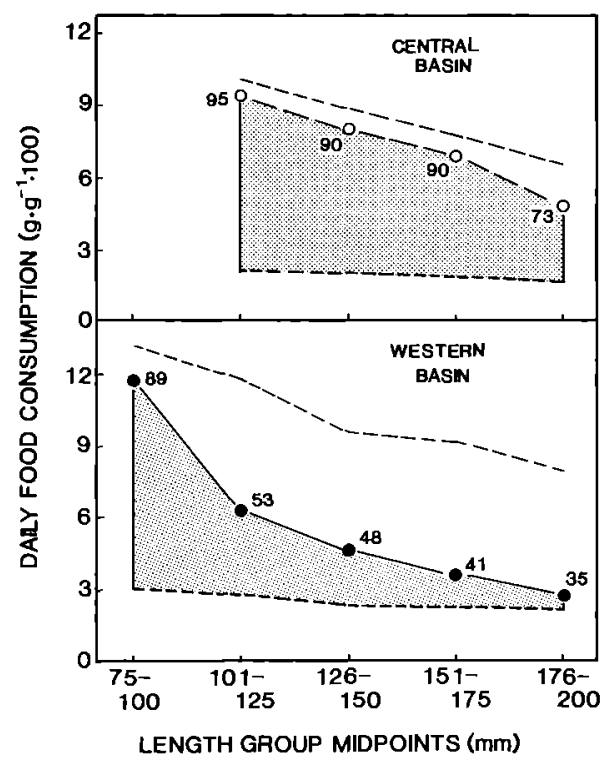

FIgURE 8.-Food consumption rates (g food $\cdot g$ fish $^{-1}$. 100 ) by $25-\mathrm{mm}$ yellow perch length groups in relation to maximum daily consumption rates (uppermost dashed lines) and maintenance rations (bottom dashed lines) during summer diel sampling in the western and central basins of Lake Erie, 1983. Values near data points show percentages of maximum daily consumption rate realized by each length group at each site.

and measured food consumption rates is expected and has been supported empirically by Swenson (1977).

\section{Eutrophication and Food Supply}

An empirically based response curve of Perca spp. "well-being" as a function of lake trophic stage was developed by Leach et al. (1977). Environmental conditions for a perch population (measured by factors such as individual growth rates and trends in population biomass) are considered to improve as a lake becomes progressively eutrophic up to an optimum trophic stage, whereupon further eutrophication leads to degradation of the population. This response has been supported further by a study of fish community trends in Polish lakes (Leopold et al. 1986). Evidence for a growth increase in central basin yellow perch and a pronounced decline for fish in the western basin since about 1970 (Figure 1) suggests that, in the context of this response curve, recent eutrophication has moved the central basin closer to an optimum trophic stage for yellow perch while the western basin has moved well beyond, into the region of degradation. Because of earlier equivalency in conditions for yellow perch growth in the western and central basins, present differences in food consumption are thought to reflect net changes in available food supply in the two basins that have resulted from eutrophication. Moreover, mechanisms underlying a eutrophication-induced decline in yellow perch food supply in the western basin (as might be seen in a historical versus present-day comparison) should be reflected in a present-day comparison between the more suitable central basin and the now-degraded western basin.

Studies of growth rates and diets of the yellow perch and the congeneric Eurasian perch Perca fluviatilis show these very similar species (Thorpe 1977b) to be planktivorous at early stages and predominantly benthivorous otherwise (Price 1963; Thorpe 1977a; Craig 1978; Nakashima and Leggett 1978). Their ability to grow rapidly and to larger sizes has been associated with availability of intermediate- and large-sized food items (MacLean and Magnuson 1977; Rask 1983; Rask and Hiisivuori 1985; Chabot and Maly 1986). Some investigators have proposed ontogenetic size limits for these species beyond which transition to larger-sized prey items is necessary for continued growth (Alm 1946; Schneider 1972). While piscivory is not uncommon in larger perch (fish being large-sized food packets), higher gut evacuation rates associated with feeding on softer-bodied benthos (Persson 1983) may partially explain an apparent preference for larger benthic invertebrates over fish in the central basin.

Increases in biomass of prey communities tend to accompany eutrophication, as do shifts in species composition towards smaller-sized individual benthic organisms (Brundin 1951; Cook and Johnson 1974; Leach et al. 1977). Some evidence suggests that a similar response also may occur within plankton communities, because size of their food particles tends to decline with eutrophication (Gliwicz 1969). Dramatic restructuring of the western basin benthic community was directly linked to eutrophication by Carr and Hiltunen (1965). The trend in the western basin benthos in response to severe eutrophication has been away from a community dominated by large-sized benthic organisms (e.g., Hexagenia spp.) towards one dominated by small-sized oligochaetes. Accompanying the demise of the large mayflies in the western basin shortly after the increase in nutrient loading rates (Britt 1955), there were declines in western basin populations of other larger-sized benthos, including trichopterans and amphipods (Carr and Hiltunen 1965). A ninefold 


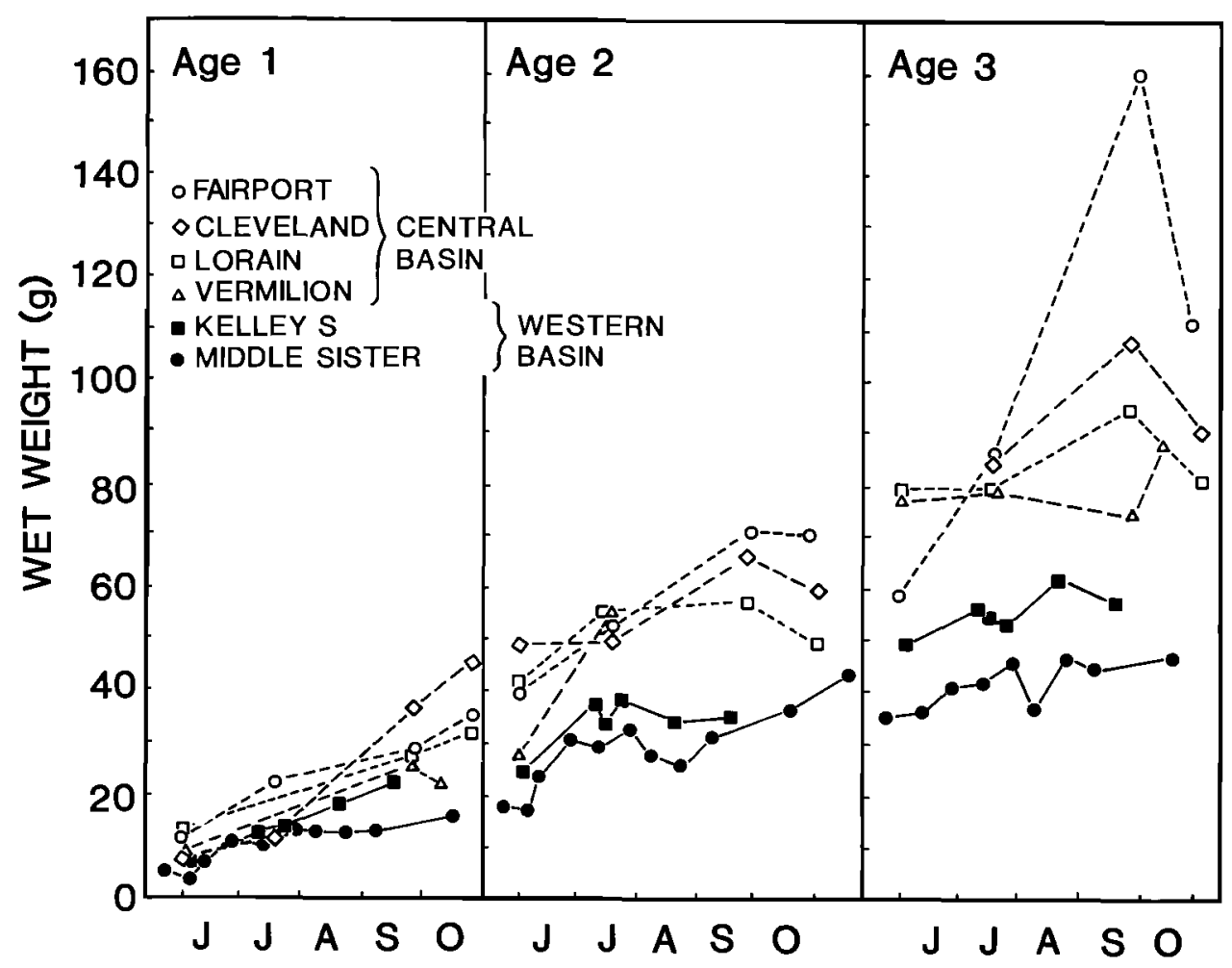

\section{MONTH}

FIGURE 9.-Mean wet weights of 1-, 2-, and 3-year-old yellow perch trawled from all sampling sites in the western and central basins of Lake Erie throughout 1983.

increase in biomass of small-sized oligochaetes was accompanied by increases in biomasses of chironomids (but fewer, and smaller-sized species), sphaeriid clams, and gastropods. Parallel individual size responses to organic enrichment have been observed in benthic communities in other Great Lakes (Colby et al. 1972; Cook and Johnson 1974), European lakes (Biro 1977; Hartmann and Numann 1977), and in nearshore marine environments (Pearson and Rosenberg 1978; Livingston 1984). German (1968) showed a bidirectional aspect to this trend in size of benthic organisms. In severely polluted Nipigon Bay, Lake Superior, benthos shifted from large- to smaller-sized forms but then returned to the former complexion after restorative action was taken.

During 1958, when restructuring of Lake Erie's western basin benthic community had only begun, yellow perch fed readily on five major taxa, including Hexagenia spp., amphipods, trichopterans, chironomids, and zooplankton (Price 1963). We observed not only a quantitively but also a qualitatively restricted diet in 1983, with only three (smaller-sized) taxonomic groups consumed in the western basin (Figure 10). In accordance with their reported declines, Hexagenia spp., trichopterans, and amphipods were either totally absent or occurred in only trace amounts in western basin fish diets in 1983. Consistent with the reported need of yellow perch for larger diet items, we observed almost no utilization of the very abundant oligochaetes by western basin fish in 1983. Apparently unable to adapt to the new small-sized forage complex, western basin yellow perch relied more exclusively on the remnants of a once more suitable (larger-sized) forage base. Higher frequency of use of chironomids and zooplankton was observed in 1983 relative to 1958 . The only new taxon added to the diets was sphaeriid clams. Heavy use of this prey group (only by larger fish), whose energetic yield per unit volume (or per handling cost) is considered low, may indicate further the paucity of present feeding alternatives for larger yellow perch in the western basin.

Fish did not contribute substantially to yellow perch diets in 1958 or in 1983 in the offshore areas 
DIET SHIFTS - WESTERN BASIN

\begin{tabular}{|c|c|c|c|}
\hline Taxa & Biomass & 1958 & 1983 \\
\hline Chironomidae & & $1(55)$ & $1(76)$ \\
\hline Zooplankton & & $2(35)$ & $2(48)$ \\
\hline Trichoptera & & $3(24)$ & $M(5)$ \\
\hline Amphipoda & & $4(24)$ & $M(1)$ \\
\hline Hexagenia spp & $\nabla$ & $5(12)$ & NONE \\
\hline Sphaeriidae & $\triangle$ & M (7) & $3(31)$ \\
\hline Gastropoda & & $M(6)$ & $M(3)$ \\
\hline Oligochaetes & & $M(1)$ & M (1) \\
\hline Fish & $=$ & $M(5)$ & M (5) \\
\hline
\end{tabular}

FIGURE 10.-Direction (arrows) of biomass change for certain forage taxa in the western basin of Lake Erie, from the 1950s through 1983, and rankings (indicated before parentheses) of their mean frequency of occurrence (inside parentheses) in stomachs of all yellow perch sampled from spring through fall in 1958 (Price 1963) and 1983. Minor contributions to diets (M) were considered to be less than one occurrence in 10 stomachs. Symbols to far right indicate the apparent direction of change in reliance on a particular item by western basin yellow perch from 1958 through 1983.

of either basin. Low use of fish by western basin yellow perch suggests that this large-sized forage group does not serve as an effective buffer against the degraded benthic forage complex in the western basin. Forage fish are utilized by yellow perch in nearshore areas of the lake (White 1975; Knight et al. 1984) where densities of small fish are presumably higher. Low densities of forage fish in 1983 (R. Knight, Ohio Department of Natural Resources, personal communication) may have biased our view of the more general role of fish forage as a buffer.

Interbasin differences in food consumption by yellow perch in 1983 reflect the change in food supply that has resulted from eutrophication. Mechanisms of a reduced food availability in the western basin can be seen by comparing 1983 diets of fish in the two basins. Just what underlies the improvement of feeding conditions for central basin yellow perch cannot be readily determined due to the lack of baseline data. Presumably, increased productivity has resulted in greater biomass of appropriately sized benthos.

\section{Size Effects and Implications}

The influence of eutrophication in the western basin has apparently been greater for larger fish.
During summer, we observed a progressive decline in food consumption rate with increasing fish size (Figure 8). The response is most vividly depicted through the use of narrower $(25 \mathrm{~mm})$ yellow perch length groups than through the broader groupings in Figure 5. Smaller individuals (75$100 \mathrm{~mm}$ ) fed at high rates in the western basin while individuals closer to $175 \mathrm{~mm}$ fed near maintenance rations. Upon reaching a length of about $100 \mathrm{~mm}$, where conversion to larger-sized food items is considered to be advantageous (Alm 1946; Schneider 1972; Rask and Hiisivuori 1985), western basin fish were food-limited, given the restructured forage base that was devoid of largesized diet items. In the central basin where eutrophy is not so advanced and a more suitable yellow perch forage complex exists, all sizes of fish fed at high levels (Figure 8).

Accentuated food limitation for larger fish favors stunting or "bottlenecking" of their sizes to a greater extent than if food availability was low, but evenly so, across fish sizes. Comparison of weight-frequency distributions of yellow perch collected in typical bottom trawl collections in the western and central basins in 1983 (Figure 11) indicates that a size "bottleneck" was present in

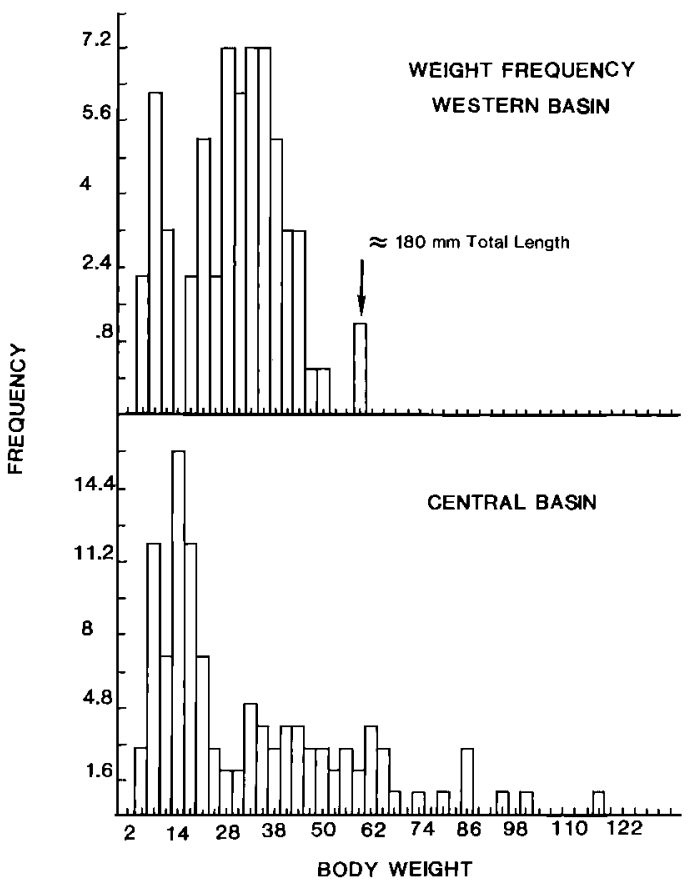

FIGURE 11.- Weight-frequency histograms of yellow perch trawled from the western (Middle Sister) and central (Fairport) basins of Lake Erie in June, 1983. Body (wet) weight in grams. 
the western basin in response to the size-related nature of food limitation. A more protracted distribution of body weights was observed at Fairport.

Stunting may result in declines in reproductive fitness and, ultimately, in biomass of the population (Vladimirov 1973; Stearns 1976; Biro 1977). In the laboratory, we observed that yellow perch provided with only maintenance rations exhibited significantly higher mortality rates from outbreaks of pathogens than did counterparts in the same water (and same tank) that received higher food levels (Hayward and Margraf, unpublished data). Such mortality may cause direct reduction of numbers of mature individuals.

Leach and Nepszy (1976) reported a reduction in frequency and magnitude of prominent year classes of yellow perch in Lake Erie since 1970, as well as a decline in commercial catch rates in the western basin, signifying fewer large individuals. Mature western basin fish appear to be feeding near or below maintenance rations not only in summer but through the fall as well (Figure 6). If so, severe negative impacts on their survival, as well as on numbers and viability of offspring produced in the following spring, would be expected (Scott 1961; Vladimirov 1973). Colby et al. (1972) speculated that a food-size-related mechanism, much like the one we have defined, could conceivably underlie declines of salmonids in oligotrophic lakes.

\section{Contrast with Density-Dependent Response}

Perca spp. are well known for their propensity to undergo rapid population expansions (Craig and Kipling 1983; Schneider 1984) and frequently exhibit density-dependent growth (Schneider 1973; Hansson 1985). It is important to distinguish between fish density as a frequent cause of low food supply and slow growth rate for these species and the very different cause underlying an ostensibly similar response in Lake Erie. We believe that yellow perch and other species undoubtedly played a role in the restructuring of the benthos described earlier through a "kingpin" scenario. Loss of major forage taxa initiated by low dissolved oxygen conditions from eutrophication (primarily Hexagenia spp.) would have elevated the predatory burden on remaining preferred prey species. These remaining taxa then faced the synergistic effects of poor water quality plus elevated predation pressure. This involvement of the predators in the restructuring of the benthos to smaller-sized individuals (Post and Cucin 1984) must be consid- ered to be a component of the eutrophication influence.

The western basin food supply for yellow perch began to decline without major increases in densities of yellow perch or other potential competitors (Ohio Department of Natural Resources 1983). All evidence indicates that, at least since 1970 , the western basin yellow perch population has, in fact, been declining (Leach and Nepszy 1976; M. Rawson, Ohio Department of Natural Resources, personal communication) undoubtedly through a suite of mechanisms that tend to equilibrate numbers with food supply. In addition, the white perch Morone americana is an estuarine invader, whose presence in both basins increased sharply in 1979 (Schaeffer and Margraf 1986). This expanding population may have exacerbated the food limitation problem for yellow perch in the western basin and perhaps also in the more favorable central basin. However, white perch arrived well after the decline in growth rates of western basin yellow perch had begun. It seems reasonable to view the recent expansion of the white perch population as a consequence of eutrophication (and perhaps a secondary mechanism of succession) whereby instability of a primary benthos-feeding resident has allowed this exotic competing species to gain a foothold. The invasion by white perch may represent a transcendence of homeostatic bounds in Lake Erie, in that its presence reduces the likelihood that the earlier complexion of the faunal community of the western basin can be regained soon, despite restorative attempts.

Reduced structural diversity of benthic prey in response to eutrophication has undoubtedly reduced the scope for food resource partitioning among fish species in Lake Erie. Hartmann and Numann (1977) observed progressive overlap in diets of whitefish Coregonus lavaretus wartmanni, burbot Lota lota, and roach Rutilus rutilus with that of the Eurasian perch in Lake Constance. Livingston (1984) likewise reported inter- and intraspecific diet convergence among fishes residing in an organically enriched, nearshore marine environment. Therefore, studies of competitive interactions among fishes should consider potential constraining effects of trophic stage.

In conclusion, our findings reinforce the need to recognize that the scope for yields of particular fish species is underlain by the trophic stage of the lake environment. Clearly, the harvesting potential for large numbers of commercial yellow perch from Lake Erie in 1983 was far less than in years 
prior to 1970 . Whether conditions for a particular species change gradually in response to eutrophication and oligotrophication, as suggested by Leach et al. (1977), or more abruptly, as suggested by our results, remains to be clarified and would have profound implications for fisheries management. The ability to predict responses of fish communities to changes in the trophic stage of lakes is particularly important now that technology and public sentiment have fostered lake oligotrophication (USEPA 1985; Sabourin et al., in press) while the problems of lake eutrophication persist. Because the succession of flora and fauna in a rejuvenating lake will probably not mirror the succession of species observed in an aging lake, measurement of change based on successional mechanisms should be superior to assessments based on description.

\section{Acknowledgments}

We thank the personnel at the Ohio Department of Natural Resources, Division of Wildlife, Lake Erie Unit, particularly D. H. Davies, R. L. Knight, and C. Baker, for their field logistics support and conceptual input. We are also indebted to P. K. Cunningham and C. T. Knight of the Ohio Cooperative Fish and Wildlife Research Unit for their dedicated efforts in the field and laboratory, and to G. G. Mittelbach for reviewing the manuscript. The study was funded through Federal Aid in Fish Restoration, Project F-35-R, Study 6, and Commercial Fisheries Research and Development, Project 3-379-R, Study 1, by contract from the Ohio Department of Natural Resources to the Ohio Cooperative Fish and Wildlife Research Unit.

\section{References}

Alm, G. 1946. Reasons for the occurrence of stunted fish populations with special regard to perch. Institute of Freshwater Research Drottningholm Report 25.

Arnold, D. E. 1969. The ecological decline of Lake Erie. New York Fish and Game Journal 16:27-45.

Barans, C. A., and R. A. Tubb. 1973. Temperatures selected seasonally by four fishes from western Lake Erie. Journal of the Fisheries Research Board of Canada 30:1697-1703.

Beeton, A. M. 1961. Environmental changes in Lake Erie. Transactions of the American Fisheries Society $90: 153-159$.

Biro, P. 1977. Effects of exploitation, introductions, and eutrophication on percids in Lake Balaton. Journal of the Fisheries Research Board of Canada 34:1678-1683.

Bradshaw, A. S. 1964. The crustacean zooplankton picture: Lake Erie 1939-49-59; Cayuga 1910-5161 . Internationale Vereinigung fuer Theoretische und Angewandte Limnologie Verhandlungen 15:700 708 .

Britt, N. W. 1955. Stratification in western Lake Erie in summer of 1953: effects on Hexagenia (Ephemeroptera) population. Ecology 36:239-244.

Brundin, L. 1951. The relation of $\mathrm{O}_{2}$ microstratification at the mud surface to the ecology of the profundal bottom fauna. Institute of Freshwater Research Drottningholm Report 32:32-42.

Carr, J. F., and J. K. Hiltunen. 1965. Changes in the bottom fauna of western Lake Erie from 1930 to 1961. Limnology and Oceanography 10:551-569.

Chabot, F., and E. J. Maly. 1986. Variation in diet of yellow perch (Perca flavescens) in a Quebec reservoir. Hydrobiologia 137:117-124.

Christie, W. J. 1974. Changes in the fish species composition of the Great Lakes. Journal of the Fisheries Research Board of Canada 31:827-854.

Colby, P. J., G. R. Spangler, D. A. Hurley, and A. M. McCombie. 1972. Effects of eutrophication on salmonid communities in oligotrophic lakes. Journal of the Fisheries Research Board of Canada 29: 975-983.

Cook, D. G., and M. G. Johnson. 1974. Benthic macroinvertebrates of the St. Lawrence Great Lakes. Journal of the Fisheries Research Board of Canada 31:763-782.

Craig, J. F. 1978. A study of the food and feeding of perch, Perca fluviatilis L., in Windermere. Freshwater Biology 8:59-68.

Craig, J. F., and C. Kipling. 1983. Reproduction effort versus the environment; case histories of Windermere perch, Perca fluviatilis L., and pike, Esox lucius L. Journal of Fish Biology 22:713-727.

Crites, J. L. 1982. Impact of the nematode parasite Eustrongyloides tubifex on yellow perch in Lake Erie. Ohio State University, Department of Zoology, Commercial Fisheries Research and Development Project 3-298-D, Study 1, Columbus.

Davis, C. C. 1964. Evidence for the eutrophication of Lake Erie from phytoplankton records. Limnology and Oceanography 9:275-283.

Elliot, J. M., and L. Persson. 1978. The estimation of daily rates of food consumption for fish. Journal of Animal Ecology 47:977-991.

Entz, B. 1971. Environmental conditions of percid waters in central Europe. Journal of the Fisheries Research Board of Canada 34:1586-1591.

German, M. J. W. 1968. Biological survey of Nipigon Bay 1966-1969. Ontario Water Resources Commission Report 1968:1-22, Toronto, Canada.

Gliwicz, Z. M. 1969. The food sources of lake zooplankton. Ekologia Polska Series B 15:205-223.

Great Lakes Basin Commission. 1976. Limnology of lakes and embayments, appendix 4, Great Lakes basin framework study. Public Information Office, Ann Arbor, Michigan.

Hansson, S. 1985. Local growth differences in perch (Perca fluviatilis L.) in a Baltic archipelago. Hydrobiologia 121:3-10. 
Hartman, W. L. 1972. Lake Erie: effects of exploitation, environmental change, and new species on the fisheries resources. Journal of the Fisheries Research Board of Canada 29:889-912.

Hartman, W. L., S. J. Nepszy, and R. L. Scholl. 1980. Minimum size limits for yellow perch (Perca fla vescens) in western Lake Erie. Great Lakes Fishery Commission Technical Report 39.

Hartmann, J., and W. Numann. 1977. Percids of Lake Constance, a lake undergoing eutrophication. Journal of the Fisheries Research Board of Canada 34: 1670-1677.

International Joint Commission. 1983. Report on Great Lakes water quality. Great Lakes Water Quality Board, Windsor, Canada.

Jobes, F. W. 1952. Age, growth, and production of yellow perch in Lake Erie. U.S. Fish and Wildlife Service Fishery Bulletin 52:205-266.

Kitchell, J. F., D. J. Stewart, and D. Weininger. 1977. Applications of a bioenergetics model to yellow perch (Perca flavescens) and walleye (Stizostedion vitreum vitreum). Journal of the Fisheries Research Board of Canada 34:1922-1935.

Knight, R. L., F. J. Margraf, and R. F. Carline. 1984. Piscivory by walleyes and yellow perch in western Lake Erie. Transactions of the American Fisheries Society 113:677-693.

Larson, D., and D. E. Rathke. 1980. Zooplankton distributions in the central and western basins of Lake Erie. Pages 272-293 in C. E. Herdendorf, editor. Lake Erie nutrient control program: an assessment of its effectiveness in controlling lake eutrophication. U.S. Environmental Protection Agency, Technical Report 600/3-80-062, Washington, D.C.

Leach, J. H., M. G. Johnson, J. R. M. Kelso, J. Hartmann, W. Numann, and B. Entz. 1977. Responses of percid fishes and their habitats to eutrophication. Journal of the Fisheries Research Board of Canada 34:1964-1971.

Leach, J. H., and S. J. Nepszy. 1976. The fish community in Lake Erie. Journal of the Fisheries Research Board of Canada 33:622-638.

Leopold, M., M. Bninska, and W. Nowak. 1986. Commercial fish catches as an index of lake eutrophication. Archiv fuer Hydrobiologie 106:513-524.

Lindeman, R. T. 1942. The trophic-dynamic aspect of ecology. Ecology 23:399-418.

Livingston, R. J. 1984. Trophic response of fishes to habitat variability in coastal seagrass systems. Ecology $65: 1258-1275$.

MacLean, J., and J. J. Magnuson. 1977. Species interactions in percid communities. Journal of the Fisheries Research Board of Canada 34:1941-1951.

McCauley, R. W., and L. A. A. Read. 1973. Temperature selection by juvenile and adult yellow perch (Perca flavescens) acclimated to $24 \mathrm{C}$. Journal of the Fisheries Research Board of Canada 30:1253-1255.

Munawar, M., and I. F. Munawar. 1976. A lakewide study of phytoplankton biomass and its species composition in Lake Erie, April-December 1970. Journal of the Fisheries Research Board of Canada 33:581-600.
Nakashima, B. S., and W. C. Leggett. 1978. Daily ration of yellow perch (Perca flavescens) from Lake Memphremagog, Quebec-Vermont, with a comparison of methods for in situ determinations. Journal of the Fisheries Research Board of Canada 35: 1597-1603.

Ohio Department of Natural Resources. 1983. Status of Ohio's Lake Erie fisheries. Ohio Department of Natural Resources, Columbus.

Pearson, T. H., and R. Rosenberg. 1978. Macrobenthic succession in relation to organic enrichment and pollution of the marine environment. Oceanography and Marine Biology: an Annual Review 16: 229-311.

Persson, L. 1979. The effects of temperature and different food organisms on the rate of gastric evacuation in perch (Perca fluviatilis). Freshwater Biology 9:99-104.

Persson, L. 1983. Food consumption and competition between age classes in a perch (Perca fluviatilis) population in a shallow eutrophic lake. Oikos 40:197207.

Post, J. R., and D. Cucin. 1984. Changes in the benthic community of a small precambrian lake following the introduction of yellow perch, Perca flavescens. Canadian Journal of Fisheries and Aquatic Sciences 41:1496-1501.

Price, J. W. 1963. A study of food habits of some Lake Erie fish. Bulletin of the Ohio Biological Survey 2: 1-89.

Rask, M. 1983. Differences in growth of perch (Perca fluviatilis L.) in two small forest lakes. Hydrobiologia 101:139-144.

Rask, M., and C. Hiisivuori. 1985. The predation on Asellus aquaticus (L.) by perch Perca fluviatilis (L.), in a small forest lake. Hydrobiologia 121:27-33.

Rathke, D. E., and C. J. Edwards. 1985. A review of trends in Lake Erie water quality with emphasis on the 1978-79 survey. Report to International Joint Commission, Surveillance Work Group, Windsor, Canada.

Regier, H. A., and W. L. Hartman. 1973. Lake Erie's fish community: 150 years of cultural stresses. Science (Washington, D.C.) 180:1248-1255.

Sabourin, T. D., R. S. Hayward, R. T. Faulk, and B. W. Cornaby. In press. Water quality improvements and nuisance biota. Report to U.S. Environmental Protection Agency, Office of Water Regulations and Standards, Washington, D.C.

Schaeffer, J. S., and F. J. Margraf. 1986. Food of white perch (Morone americana) and potential for competition with yellow perch (Perca flavescens) in Lake Erie. Ohio Journal of Science 86:26-29.

Schneider, J. C. 1972. Dynamics of yellow perch in single species lakes. Michigan Department of Natural Resources, Research and Development Report 184, Ann Arbor.

Schneider, J. C. 1973. Density dependent growth and mortality of yellow perch in ponds. Michigan Department of Natural Resources, Fisheries Research Report 1795, Ann Arbor.

Schneider, J. C. 1984. Yellow perch maturity and fe- 
cundity as a function of age and growth. Michigan Department of Natural Resources, Fisheries Research Report 1915, Ann Arbor.

Scott, D. P. 1961. Effects of food quantity on fecundity of rainbow trout, Salmo gairdneri. Journal of the Fisheries Research Board of Canada 19:715-731.

Sly, P. G. 1976. Lake Erie and its basins. Journal of the Fisheries Research Board of Canada 33:355370.

Snieszko, S. F. 1974. The effects of environmental stress on outbreaks of infectious diseases of fish. Journal of Fish Biology 6:197-208.

Stearns, S. C. 1976. Life-history tactics: a review of the ideas. Quarterly Review of Biology 51:3-47.

Swenson, W. A. 1977. Food consumption of walleye (Stizostedion vitreum vitreum) and sauger ( $S$. canadense) in relation to food availability and physical conditions in Lake of the Woods, Minnesota, Shagawa Lake, and western Lake Superior. Journal of the Fisheries Research Board of Canada 34:16431654.

Thorpe, J. E. 1977a. Daily ration of adult perch (Perca fluviatilis L.) during summer in Lock Leven, Scotland. Journal of Fish Biology 1 1:55-68.

Thorpe, J. E. 1977b. Morphology, physiology, behavior, and ecology of Perca fluviatilis L. and Perca flavescens Mitchill. Journal of the Fisheries Research Board of Canada 34:1504-1514.

USEPA (United States Environmental Protection Agency). 1985. Clean lakes program: a review of the first decade. USEPA, 440/5-85-003, Washington, D.C.

Vladimirov, V. I. 1973. The effect of growth rate of spawners on the survival and abundance of the progeny. Journal of Ichthyology 13:801-812.

Vollenweider, R. A., M. Munawar, and P. Stadlemann. 1974. A comparative review of phytoplankton and primary production in the Laurentian Great Lakes. Journal of the Fisheries Research Board of Canada 31:739-762.

White, A. M. 1975. Planktonic communities, benthic assemblages, and fishery. Appendix A in R. A. Sweeney, editor. Aquatic disposal field investigations Ashtabula River disposal site, Ohio. State University of New York, Great Lakes Laboratory, Technical Report D-77-42, Buffalo.

Wright, S. 1955. Limnological survey of western Lake Erie. U.S. Fish and Wildlife Service Special Scientific Report Fisheries 139.

Received January 13, 1986 Accepted March 4, 1987 